\title{
Representasi Budaya Masyarakat Aceh Dalam Diaspora Jalur Transnasional Pengungsi Etnis Rohingya
}

\author{
Muhammad Ichsan \\ Magister Kajian Asia Tenggara, \\ Fakultas Ilmu Budaya Universitas Indonesia \\ muhammad.ichsan94@ui.ac.id
}

Received: 12 Januari 2021; Revised: 26 Februari 2021; Accepted: 28 April 2021 DOI: http://dx.doi.org/10.37905/aksara.7.2.215-224.2021

\begin{abstract}
ABSTRAK
Masyarakat Aceh memiliki sosial budaya yang diakui global. Pasca tsunami, masyarakat Aceh telah merepresentasikan karakter yang dinamis dengan adaptasi baru yang sangat cepat. Sejak tahun 2015 hingga 2020 banyak masyarakat global yang datang melihat rekonsiliasi perdamaian serta pembangunan di Aceh. Tahun 2015 awal bagi Aceh dikenal dengan wilayah transnasional di Asia Tenggara yang menerima pengungsi etnis rohingya. Peneliti melihat perubahan dalam sosial masyarakat Aceh dalam melayani pengungsi rohingya serta berperan dalam adaptasi baru dikawasan tersibuk yaitu selat malaka. Maka peneliti akan menggunakan metode Etnografi dan Netnografi dalam mendapatkan kesimpulan bagaimana sikap masyarakat Aceh dalam menerima pengungsi etnis rohingya tersebut.

Kata kunci : Transnasional, Etnis Rohingya, Aceh, Selat Malaka, Asia Tenggara
\end{abstract}

\section{ABSTRACT}

The people of Aceh have a socially recognized culture globally. After the tsunami, the people of Aceh have represented a dynamic character with new adaptations very quickly. From 2015 to 2020, many global communities have come to see the reconciliation of peace and development in Aceh. In early 2015, Aceh was known as the transnational region in Southeast Asia that received Rohingya ethnic refugees. Researchers saw changes in the Acehnese society in serving Rohingya refugees and played a role in new adaptations in the busiest region, namely the Malacca Strait. Then the researcher will use Ethnographic and Netnographic methods in getting a conclusion about the attitude of the Acehnese people in accepting these Rohingya ethnic refugees.

Keywords: Transnational, Rohingya Ethnicity, Aceh, Malacca Strait, Southeast Asia

\section{PENDAHULUAN}

Pandemi Covid turut membawa berkah bagi tanah Aceh. Selain Provinsi yang terletak strategis di ujung pulau Sumatera juga turut menjadi persinggahan wisatawan global. Selain wisatawan, Aceh juga termasuk jalur Transnasional pengungsi Etnis minoritas seperti Rohingya. Berbicara mengenai sosiologi dan antropologi, maka unsur manusia, budaya, suku, dan juga adat akan menjadi pusat perhatian dalam setiap pembicaraan atau pembahasan. Indonesia merupakan negara yang kaya akan keragaman budaya dan apabila kita mengkaji soal budaya maka adat adalah topik penting yang tidak dapat dipisahkan, karena adat merupakan bagian daripada kebudayaan, meskipun masih terdapat beberapa aspek yang tidak 
kalah penting dalam mengkaji soal kebudayaan. Aceh adalah sebuah masyarakat yang menetap di ujung pulau Sumatera wilayah Indonesia. Hampir seluruh penduduk Aceh adalah beragama Islam yang taat. Selain itu, Aceh juga terkenal sebagai wilayah pertama sekali kemunculan Islam di Asia Tenggara. Masyarakat Aceh terkenal dengan ketaatannya terhadap agama dan sangat menjunjung tinggi budaya serta adat-istiadatnya. Sebelum Islam datang ke Aceh, pengaruh Hindu dan Budha sudah berakar dalam tradisi dan kepercayaan masyarakat Aceh. Menurut Geertz (1983) Aceh sebagai contoh perluasan globalisasi di ranah lokal hampir dapat disebut sebagai desa global yang dinamis. Masuknya kultur global di Aceh seharusnya bukan menjadi hal yang negatif bagi perkembangan kebudayaan dan pengetahuan lokal, tetapi setidaknya mampu konsisten dalam konteks usaha memperkuat identitas lokal yang dinamis. Akan tetapi, ternyata pola-pola konfrontatif pertemuan dua identitas "lokal dan global" kini berlangsung dengan kritis dan tampak berhadap-hadapan (Woodward, 1997. 84). Tidak saja itu, meluasnya globalisasi di Aceh dalam tahun-tahun belakangan juga ikut mendukung dialektika lokal dan global di Aceh secara lebih intensif dan sistematis. Terlepas dari interaksi lokal-global yang demikian intens ini, pertemuan keduanya telah memberi pelajaran berharga bagi masyarakat lokal, tidak saja dalam bidang ekonomi-politik dan keamanan, tetapi di bidang sosial-budaya juga (Friedmen, 1991: 134).Oleh karenaitu, diperlukandiplomasi diaspora agar diaspora tersebut berlangsung dengan baik dan diterima oleh kedua belah pihak yang terkait.

\section{KAJIAN TEORI}

\section{Perkembangan diplomasi dalam diaspora budaya}

Lompatan terbesar dalam perkembangan studi diplomasi terjadi pada saat terbentuknyasistem Westphalia, di mana terjadi formalisasi atas penggunaan diplomasi setelah pertemuannegara-negara di Ossnabruck dan Munster. Pada saat itu, diplomasi merupakan bagian yangsejalan dengan kedaulatan negara, serta dilaksanakan secara khusus oleh staf-staf pemerintahan. Walaupun demikian, dalam perkembangannya pelaksanaan diplomasi tidak lagi hanya dilakukanoleh staf-staf pemerintahan karena diplomasi dapat dilakukan pula oleh berbagai aktor nonnegara. Selain itu, diplomasi kontemporer memperbolehkan para penstudi dan praktisis diplomasi untuk memperlebar cakupan diplomasi yang ditandai dengan mulai berkembangnya bidang-bidang diplomasi seperti diplomasi ekonomi, militer, e-diplomacy dan diplomasi budaya. Pembahasan mengenai korelasi antara budaya dan diplomasi telah dilakukan sejak permulaan peradaban. Namun, studi hubungan internasional hanya menaruh sedikit perhatian atas eksistensi dari kebudayaan, bila dibandingkan dengan perspektif politik serta ekonomi. Pada awalnya, diplomasi budaya merujuk pada potensial dari eksprei budaya melalui pertukaran ide serta informasi di antara masyarakat guna meningkatkan pemahaman mutual (Scheneider, Dkk ,2006). Diplomasi budaya telah dilakukan pada masa Roman empire dimana dignitaries (delegasi) diberikan pelatihan mengenai kebudayaan Italia yang kemudian secara tidak langsung turut memperkenalkan kebudayan Italia sekembalinya mereka ke tanah airnya (Keer \& Wiseman 2013). Namun, mencapai masa-masa keemasannya pada masa Perang Dingin yang kemudian secara perlahan meredup bersamaan dengan kemenangan Amerika Serikat. 


\section{Sejarah Singkat Transnasional dan Migrasi rohingya}

Dalam buku berjudul Transnational Democracy yang dieditori oleh James Anderson (2002) , diulas tentang berbagai fenomena yang menarik untuk diperhatikan, di antaranya adalah meningkatnya penyeberangan perbatasan (negara), adanya (disrupted) ruang politik lama, kemunculan ruang kehidupan sosial yang baru, dan terjadinya 'defisit demokrasi' secara umum atau global. Berbagai karakter dan bentuk perubahan global telah mengancam berbagai karakter dan bentuk representasi demokratis dan akuntabilitas konvensional. Peristiwa 10 Mei 2015 tersebut merupakan gelombang pertama pengungsi Rohingya Myanmar dan Bangladesh yang secara tiba-tiba datang membanjiri dan memasuki wilayah Indonesia, tepatnya di Aceh Utara. Kedatangan para migran tersebut membuat masyarakat dan Pemerintah Indonesia terkejut. Tidak hanya masyarakat dan Pemerintah Indonesia saja, melainkan juga masyarakat internasional, regional dan berbagai organisasi-organisasi kemanusiaan turut terkejut dengan temuan para nelayan Aceh atas aktifitas pengungsi Rohingya Myanmar dan Bangladesh tersebut di perairan laut Indonesia, terlebih dalam kondisi para pengungsinya yang diketahui kemudian sangat memprihatinkan.

Dimana jika meminjam kategorisasi faktor-faktor yang melandasi terjadinya migrasi internasional menurut Castles dan Loughna, berbagai variabel penting yang membuat etnis Rohingya Myanmar melarikan diri dari wilayahnya, seperti tekanan pemerintah negaranya melalui kebijakan kependudukan yang tidak mengakui etnis Rohingya, fakta sejarah yang menunjukkan bahwa etnis Rohingya lebih dekat ke Bangladesh di banding ke Myanmar. Posisi minoritas yang diemban oleh etnis Rohingya serta kondisi perekonomian dan tingkat kesejahteraannya yang sangat memprihatinkan merupakan bagian dari aspek push-pull yang menjadi dasar terjadinya migrasi internasional secara masif.

\section{Representasi Budaya Masyarakat Aceh dalam Menerima Tamu}

adat dan kebiasaan masyarakat Aceh menyambut dan menerima tamu yang datang berkunjung adalah hal yang sangat penting. Tamu bagi masyarakat Aceh adalah "raja" yang harus dimuliakan. Adapun mengapa tamu disebut raja disebabkan dalam ajaran Islam wajib bagi tuan rumah untuk menerima kedatangan tamu dengan hati gembira. Karenanya tuan rumah harus melayani tamunya dengan baik, memuliakannya dan ramah terhadap mereka. Cara menyambut tamu seperti itu sudah menjadi adat yang turun temurun dari sejak dulu. Pada zaman dulu ketika tamu datang, tuan rumah selalu menyuguhkan sirih saat sang tamu baru masuk diruang tamu. Sambil berbincang-bincang sirih pun disajikan. Makna sirih tersebut sebagai bentuk memuliakan dan keakraban. Hingga saat ini tradisi tersebut tetap dipertahankan, meskipun hari ini sudah memasuki era milenium namun adat peumulia jamee masih tetap hidup dalam budaya masyarakat Aceh. Kasus yang terjadi saat ini pada pengungsi Rohingya Myanmar yang terdampar di Aceh, dapat digolongkan sebagai pengungsi yang melakukan aktifitas migrasi karena faktor-faktor yang menjadi pendorong maupun penarik hingga mereka terpaksa dalam kondisi yang tidak layak untuk manusia. Jika mereka tiba di negara tujuan yang diinginkan, namun karena terdampar di negara ketiga (Aceh-Indonesia) 
mereka menjadi tergolong pengungsi internasional karena faktor ketiga, dan mereka menjadi patut mendapatkan pertolongan dan perlindungan sesuai dengan hukum dan aturan pengungsi yang berlaku secara internasional. Selagi Indonesia, Malaysia dan Thailand berunding, rombongan ketiga pengungsi kembali mendarat lagi di pantai laut Aceh.

\section{METODE PENELITIAN}

Jurnal ini mengunakan metode penelitian Etnografi dan Netnografi. Metode Etnografi merupakan desain penelitian kualitatif, seorang peneliti mendeskripsikan dan menginterpretasi pola-pola yang saling dipertukarkan dan dipelajari dari kelompok budaya tentang nilai-nilai, kebiasaan, kepercayaan dan bahasa (Creswell, 2007: 68).Kemudian berkembang pula menjadi metode etnografi komunikasi yang digagas Dell Hymes melalui artikel "The Etnography of speaking" yang diterbitkan pada 1962. Etnografi komunikasi memulai pertanyaan pada pola-pola bahasa yang digunakan dalam berkomunikasi di sebuah komunitas (Saville-Troike, 2003:3). Sedangkan penelitian dengan metode netnografi yaitu bentuk etnografi yang diadaptasi untuk dunia sosial yang dimediasi perangkat computer (Kozinet, 2010: 68). Netnografi didefinisikan sebagai metodologi riset kualitatif yang mengadaptasi teknik riset etnografi untuk mempelajari budaya dan komunitas yang terjadi dalam komunikasi termediasi computer (computer mediated communications) (Kozinets, 2002:65).Pendekatan yang dilakukan menggunakan Netnografi. Netnografi difokuskan pada studi tentang media sosial. Netnografi juga merupakan sebuah metode untuk mempelajari cybernetics space (cyberspace) dari tekstual yang diinformasikan untuk mempelajari budaya dan masyarakat yang muncul di online. Netnografi merupakan satu- satunya metode yang secara khusus dirancang untuk mempelajari kebudayan dan komunitas online (Bowler, Jr, 2010). Metode tersebut akan mencari istilah yang tidak diucapkan secara lisan yang merupakan keistimewaan dari sebuah komunitas virtual.,

\section{HASIL DAN PEMBAHASAN}

\section{Akar Konflik}

Sebelum masuk ke akar konflik, lebih baiknya kita mengetahui tentang negara Myanmar itu sendiri. Wilayah Myanmar terbagi menjadi 7 negara bagian yang dinamai ber-dasarkan etnis minoritas. Sebagai wilayah yang masuk ke dalam Asia tenggara, Myanmar memiliki ibukota di Yangoon dengan dikelilingi oleh banyak Negara yaitu Tiongkok, India, Laos, Thailand dan Bangladesh. Terdapat lebih dari 135 kelompok etnik yang masing- masing memiliki budaya dan bahasanya sendiri-sendiri. Etnis terbesar adalah Burma (Bamar).Mereka berasal dari Sino-Tibet dantinggal di dataran tengah Myanmar.Agama mayoritas etnis Burmaadalah Budha Theravada. Merekajuga menguasai pemerintah danmiliter dan tentunya menjadi etnismayoritas di Myanmar. Namun hal lain terjadi di negara bagian Rakhine yang berbatasan dengan Bangladesh. Di wilayah ini terdapat etnis Rakhine yang beragama Islam/ Arakan. Jumlah etnis Rohingya diperkirakan meliputi $4 \%$ dari penduduk Rakhine, tetapi bila dibanding dengan jumlah penduduk Rakhine yang Budha, muslim Rohingya menjadi kelompok minoritas di Myanmar secara umum jika dibandingkan dengan etnis Burma (Raharjo, 2015: 39). 
Awal mula konflik ini terjadi sejak pemerintahan Junta Militer merebut kekuasaan melalui kudeta pada tahun 1962, politik diskriminasi terhadap etnik minoritas mulai diberlakukan terutama terhadap etnis Rohingya yang dianggap bukan orang asli Burma. Pada tahun 1962 ketika Jendral Ne Win melakukan Kudeta hingga Ne Win menjadi Presiden, sistem politik Myanmar langsung berubah menjadi lebih otoriter. Etnis rohingya dianggap rezim $\mathrm{Ne}$ Win sebagai sebuah ancaman sehingga dilancarkanlah sebuah operasi untuk menumpas pergerakan separatis dan mengontrol penduduk Rohingya pada tahun 1978 (Triono, 2014: 2), dan mengakibatkan hijrahnya etnis Rohingya ke Bangladesh. Pada masa rezim Ne Win hingga tahun 2000, etnis Rohingya mengalami keadaan diskriminasi yang sangat berat. Kebijakan Burmanisasi dilakukan melalui marginalisasi orang-orang Muslim Rohingya. Munculnya kebijakan ini pada tahun 1982 yang disebut Burma Citizenship Law (BCL), yaitu Rohingya tidak mendapat kewarganegaraan, hak atas tanah, dan pendidikan serta pekerjaan yang layak dan cukup (Mitzy, 2014: 154) . Akses mereka untuk berpindah, menikah, dan mencari pekerjaan dibatasi dan harus mendapat izin terlebih dahulu dengan membayar uang sogokan. Mereka juga hanya diperbolehkan untuk memiliki maksimal dua anak per keluarga dan tidak diberikan sertifikat kelahiran untuk anak mereka. Hak anak-anak Muslim Rohingya untuk mengakses pendidikan dan pelayanan kesehatan dasar juga sangat dibatasi. Upaya - upaya lainnya yang dilakukan junta militer Myanmar adalah mempengaruhi gaya hidup etnis Rohingya yang beragama Islam untuk pindah ke agama Budha. Pada masa rezim militer mulai era Ne Win berkuasa hingga tahun 2000, etnis Rohingya mengalami situasi yang berat, hingga puncaknya konflik mengalami eskalasi pada tahun 2012, di mana pemberitaan media internasional mulai mem- buka fakta-fakta terjadinya konflik yang ada di Rohingya. Adanya kasus ini kemudian memancing etnis Rakhine yang kemudian berujung pada lingkaran konflik yang tidak terhenti. Pada Juli 2012, konflik ini memuncak dengan adanya pembakaran besar-besaran terhadap perumahan yang dihuni oleh etnis Rohingya serta penyerangan yang dilakukan oleh kedua etnis (Triono, 2014: 2 -3).

Banyak faktor yang menjadi pemicu awal meledaknya konflik di Provinsi Rakhine terhadap etnis Rohingya. Tidak hanya pemerintahan yang otoriter atau kejam dalam memimpin rakyatnya, tetapi konflik yang terjadi juga terletak pada penggolongan etnis. Akar yang menjadi awal konflik ini terjadi ialah adanya kecemburuan sosial terhadap etnis Rohingya yang dalam beberapa dasawarsa terus meningkat. Meskipun sebagai etnis minoritas 1 tetapi etnis Rohingya mampu terlibat dan bekerja dalam pemerintahan Myanmar. Hal ini menyebabkan kecurigaan dan kecemburuan pada etnis mayoritas Rakhine. Bagi mereka keberadaan etnis Rohingya dianggap dianggap sebagai sesuatu yang mengganggu dan mengurangi hak lahan dan ekonomi, khususnya di wilayah Arakan, Rakhine yang menjadi pusat kehidupan etnis Muslim. Kemudian pada tahun 1962 UndangUndang Kewarganegaraan Burma tahun 1982 telah meniadakan Rohingya sebagai etnis di Myanmar. Selanjutnya peniadaan ini adalah menghilangkan dan membatasi etnis Rohingya dalam hal yaitu: hak untuk bebas bergerak dan berpindak tempat, hak untuk menikah dan memiliki keturunan, hak atas Pendidikan, hak untuk berusaha dan berdagang, hak untuk bebas berkeyakinan dan beribadah, dan hak untuk bebas dari penyiksaan dan kekerasan (Islamedia, 2012). Sejatinya Etnis 
Rohingya tidak ada niatan memisahkan diri dan merdeka dari Myanmar, mereka hanya ingin diakui sebagai warga negara Myanmar yang berhak untuk hidup bebas dari rasa takut dan kemiskinan serta bebas berekspresi dan beribadah dalam menjalankan agamanya.

\section{Tindakan Pelanggaran}

HakAsasi Manusia Terhadap Rohingya Konflik etnis antara mayo- ritas Rakhine dan minoritas Rohingya telah berlansung lama yang menyebabkan terjadinya pelanggaran seperti pembunuhan, pembakaran rumah, dan tidak diakui etnis Rohingya sebagai salah satu bagian dari Negara Myanmar. HAM merupakan hak yang melekat kuat dan tidak bisa dipisahkan dari kehidupan manusia. HAM mengalami perkembangan pada tiga generasi. Generasi pertama berkaitan dengan hak sipil dan politik yang berdasarkan pada prinsip kebebasan individu. Generasi kedua berkaitan dengan hak ekonomi, sosial dan kebudayaan yang lebih ditujukan kepada manusia dalam hubungannya dengan kelompok masyarakat lain. Generasi ketiga adalah hak -hak asasi manusia, yang menjadi hak bangsa-bangsa dan memperoleh dasarnya dalam solidaritas bangsa- bangsa, seperti hak bangsa-bangsa untuk menentukan nasib sendiri, hak untuk perdamaian, untuk kemajuan, untuk lingkungan yang layak untuk hidup, dan lain-lain (Baehr, 2001). Namun, dalam kenyataanya di Myanmar hak-hak diatas tidak didapatkan oleh etnis Rohinya. Justru mereka mendapatkan perlakuan tidak adil dari pemerintah Myanmar yang membatasi hak-hak mereka termasuk hak untuk hidup. Pelang- garan HAM yang dilakukan oleh pemerintah Myanmar adalah adanya tindakan pemerkosaan, pembunuhan serta pembakaran rumah- rumah etnis Rohingya. Adapun tindakan diksriminasi yang dilakukan terhadap etnis Rohingya hingga pencabutan kewarganegaraan mereka. Akhirnya, etnis Rohingya menjadi warga stateless. etnis Rohingya menjadi statelles karena adanya diskriminasi serta pencabutan terhadap status kewarganegaraan. Myanmar meng- hapus Rohingya dari delapan etnis utama yaitu Burmans, Kachin, Karen, Karenni, Chin, Mon, Arakan, Shan, dan dari 135 kelompok etnis lainnya.

Pemerintah Myanamar membuat kebijakan Burmanisasi terhadap warga negara Myanmar yang dengan jelas membuktikan bahwa adanya tindakan diskriminasi. Kebijakan Burmanisasi berarti hanya mengakui adanya agama Budha di Myanmar. Tetapi dalam kenyataannya, ada agama lain yang menetap di Myanmar termasuk Islam (etnisRohingya). Etnis Rohingya yang terlibat dalam politik pemerintahan Myanmar seperti menteri, sekertaris parlemen, dan sebagian di posisi pemerintahan lainnya, dicabut hingga pemberlakuan hukum bahwa etnis Rohingya maksimal hanya mempunyai dua anak. Tindakan lain yang dilakukan adalah menghapus semua sekolah -sekolah Islam yang selama ini sudah berjalan. Kebijakan ini membuat perlakuan diskriminasi terhadap etnis Rohingya serta pencabutan status kewarganegaraan. Akibatnya, etnis Rohingya mencari kenyamanan dengan mengungsi ke beberapa wilayah seperti Malaysia, Indonesia dan Bangladesh. Tentunya etnis Rohingya berhak mendapatkan perlindungan hak asasinya. Perlakuan buruk yang terjadi terhadap etnis Rohingya telah dijelaskan di bagian akar konflik yaitu ketika masa pemerintahan Ne Win tahun 1962. Hingga puncaknya pada tahun 2012 di mana penduduk dari etnis Rakhine menyerang bis 
dan membunuh 10 orang muslim yang diduga oleh etnis Rakhine sebagai Rohingya yang berada dalam bis. Tuduhan tersebut dikarenakan 3 orang Muslim Rohingya telah memperkosa dan membunuh perempuan yang berasal dari etnis Rakhine. Sehingga permasalahan ini meluas hingga menyebabkan ratusan korban kelompok etnis Rohingya, puluhan ribu rumah dibakar, dan ratusan orang ditangkap secara paksa (Susanti, 2014:5). Tindakan-tindakan kekerasan yang ditujukan kepada kaum Rohingya telah berlansung

lama dan akan berpengaruh terhadap psikologi mereka terutama anak-anak. Anak- anak yang merasa tidak nyaman dan akan mengalami kesulitan dalam melakukan berbagai tindakan. Tidak hanya anak-anak, orang tua juga akan kesulitan dalam melakukan atau mencari pekerjaan untuk memenuhi kebutuhan setiap hari. Hal ini dikarenakan akses mereka dalam hal mencari pekerjaan bahkan hidup pun diatur dan dilarang oleh pemerintah Myanmar. Oleh sebab itu timbul rasa tidak aman dan merasa nyaman di tempat mereka sendiri dan akhirnya memilih untuk keluar dari Myanmar. Namun, sebagian warga Rohingya masih memilih untuk menetap di Rakhine meskipun keadaan mereka sering terancam dan tidak diakui. Ada alasan kenapa sebagian masyarakat Rohingya masih tetap tinggal di Rakhine karena mereka merasa bahwa Rakhine adalah tempat asal mereka dan sudah sangat lama mereka berdomisili di tempat tersebut. Bahkan sebagian warga pernah terlibat dan berpartisipasi dalam dunia politik Myanmar. Sebagian dari mereka juga mengalami kesulitan dalam mengungsi ke wilayah lain karena akses dan transportasi yang begitu sulit.

\section{Dibalik Sikap BerbedaMasyarakat Aceh dalam Menerima Etnis Rohingya}

Kasus pengungsi asal Rohingya yang masuk ke Indonesia merupakan suatu bentuk masalah illegal migration yang harus segera ditangani dengan serius. Masalah pengungsi Rohingya ini merupakan suatu masalah yang kompleks. Maka daripada itu, penanganan masalah tersebut harus menggunakan cara-cara yang saling berkaitan, mulai dari tatanan domestik/ nasional sampai ke tingkat kerja sama internasional. Kurangnya perhatian serta penanganan mengenai masalah Rohingya membuat kondisi para pengungsi Rohingya semakin memprihatinkan. Hal ini disebabkan karena faktor internal dan faktor eksternal. Faktor internal yang dimaksud adalah permasalahan yang berasal dari pemerintah Indonesia sendiri, seperti kurangnya regulasi hukum yang lengkap mengenai pengungsi. Sedangkan faktor eksternalnya yaitu belum diratifikasinya Konvensi Wina 1951 oleh Pemerintah Indonesia. Penanganannya pun bisa dilaksanakan melalui dua faktor tersebut, yaitu dengan cara menghubungkannya ke dalam konvensi tahun 1951 tentang pengungsi. Indonesia juga harus ikut berperan aktif dalam penyelesaian masalah ini agar arus pengungsi, terutama yang telah berada di Aceh segera terselesaikan. Semua pihak yang bersangkutan juga harus turut serta dalam penyelesaian masalah tersebut sampai ke akarnya karena selama masalah yang ada di Arakan belum selesai, maka arus pengungsi akan terus terjadi sepanjang waktu (Aryanto, 2013).

Kedatangan pengungsi Rohingya di atas perahu di pesisir Aceh menimbulkan pertanyaan tentang sikap masyarakat Aceh dalam menerima pengungsi dan nasib para pengungsi Rohingya di masa depan. Pada akhir Juni 2020, 99 pencari suaka 
Rohingya tiba dengan perahu di pantai Provinsi Aceh, Indonesia usai terdampar di laut selama lebih dari 120 hari. Ketika pihak berwenang mempertimbangkan apakah akan mengizinkan para pencari suaka untuk turun dari perahu, penduduk setempat dari desa nelayan terdekat mengambil inisiatif untuk menyambut pengungsi Rohingya. Mereka membantu para pengungsi Rohingya ke tempat aman, kebanyakan wanita dan anak-anak. "Di mana-mana mereka menolak kami, hanya di Aceh mereka menerima kami," tutur seorang pria Rohingya ketika telah berada di darat. Malaysia sebelumnya menoleransi kedatangan puluhan ribu pencari suaka Rohingya dan mengkritik persekusi Myanmar terhadap sebagian besar minoritas Muslim. Namun, negara itu kini mengklaim "secara tidak adil" diharapkan untuk membantu pengungsi Rohingya di tengah iklim xenofobia yang dipicu oleh pandemi COVID-19. Negara tetangga

Asia Tenggara lainnya juga enggan memberikan bantuan berarti. (Matamatapolitik.com : 2020) Pertama, penjelasan paling umum adalah solidaritas Islam. Di Aceh, 98 persen orang memeluk agama Islam. Menjadi orang Aceh hampir identik dengan identitas menjadi umat Muslim. Meskipun motivasi orang Aceh untuk membantu sesama umat Muslim lainnya mungkin tampak sebagai penjelasan yang persuasif, hal itu tidak menjelaskan kemurahan hati mereka terhadap pengungsi non-Muslim. Misalnya, pada 2016, penduduk Aceh membantu pencari suaka Hindu Tamil dari Sri Lanka. Kedua, sistem hukum adat maritim Aceh yang dikenal dengan Panglima Laot mewajibkan seluruh nelayan di Aceh untuk membantu masyarakat yang kesusahan di laut. Sistem Panglima Laot telah ada setidaknya sejak abad ke-17. Seperti hukum adat lainnya di Aceh, Panglima Laot didasarkan pada Syariah Islam. Sistem itu mengatur semua aspek perikanan serta kehidupan desa di masyarakat pesisir. Max Walden dan Balawyn Jones dalam analisis mereka di The Conversation, tradisi budaya Aceh yang kuat dalam menghormati tamu, yang dikenal sebagai Peumulia Jamee, dapat menjelaskan kebaikan hati kepada pengungsi Rohingya saat mereka sudah berada di darat. Beberapa peneliti berpendapat, ini adalah elemen penting keramahtamahan orang Aceh kepada Rohingya, khususnya anak-anak. Ketiga, pengalaman konflik dan bencana alam di Aceh menginformasikan cara pandang masyarakat Aceh terhadap diri mereka sendiri dan orang lain. Antara 1976 dan 2005, Gerakan Aceh Merdeka (GAM) melawan pemerintah Indonesia dalam konflik sipil yang berkepanjangan untuk meraih kemerdekaan. Selama konflik tersebut, banyak orang Aceh yang mengungsi. Beberapa bahkan mencari suaka di negara tetangga seperti Malaysia dan Australia.

Konflik terus berlanjut di bawah kepemimpinan 5 presiden Indonesia yang berbeda. Pada 25 Desember 2004, tsunami melanda Aceh, menyebabkan kehancuran dan korban jiwa yang belum pernah terjadi sebelumnya. Lebih dari 130 ribu orang tewas, lebih dari 37 ribu dilaporkan hilang, dan setengah juta orang mengungsi. Bencana tersebut menyebabkan masuknya ribuan pekerja bantuan asing untuk membantu upaya rekonstruksi. Tsunami juga menjadi katalisator perdamaian, dengan Kesepakatan Damai Helsinki diselesaikan pada 15 Agustus 2005. Masyarakat Aceh mengingat dengan jelas dan terus menderita dampak konflik sipil maupun tsunami. 
Apa yang masyarakat Aceh lakukan terhadap para pengungsi ini, kata Chiewy, ternyata menjadi bagian dari budaya peumulia jamee. "Kami terinspirasi budaya mulia ini, karenanya kami ingin membuatnya menjadi sebuah film dokumenter. Film ini nantinya menjadi tugas akhir kami sebagai mahasiswi di NTU," jelas sutradara film dokumenter ini. Di ICS Blang Adoe, keempatnya mewawancarai sejumlah relawan, yang selama ini menghabiskan waktu di sana dan terlibat langsung dalam penanganan pengungsi etnis Rohingya. Banyak sekali tantangan yang dihadapi pada saat awal penanganan, karena adanya perbedaan bahasa, budaya dan karakter antara para relawan asli Aceh dengan pengungsi Rohingya.

\section{PENUTUP}

Sikap Indonesia menerima para pengungsi Rohingya karena adanya kesamaan identitas sebagai negara yang menjunjung tinggi norma HAM dan pengungsi Rohingya adalah korban dari pelanggaran HAM di negara asalnya Myanmar. Sebagai bagian dari masyarakat internasional, Indonesia telah menunjukkan sikap yang perduli dan mau menampung para pengungsi Rohingya, padahal Indonesia bukanlah salah satu negara yang menandatangani dan meratifikasi Konvensi PBB tahun 1951 (tentang pengungsi), bisa saja bila Indonesia tidak mau menerima pengungsi di wilayahnya dan tidak akan terkena sanksi yuridis. Apa yang masyarakat Aceh lakukan terhadap para pengungsi ini ternyata menjadi bagian dari budaya peumulia jamee.

Saat ini dalam menangani masalah pengungsi lintas batas negara, Indonesia belum memiliki regulasi hukum yang jelas. Indonesia juga belum meratifikasi Konvensi Wina 1951 dan Protokolnya Tahun 1967 tentang Pengungsi. Hal ini mengakibatkan Pemerintah Indonesia tidak mempunyai kewajiban dan kewenangan dalam melakukan tindakan internasional mengenai pengungsi Rohingya yang masuk ke Aceh secara lebih jauh. Indonesia hanya dapat menampung sementara serta memberikan fasilitas dan kebutuhan-kebutuhan pokok yang diperlukan pengungsi selama berada di Aceh, kemudian selebihnya akan diproses dan ditindaklanjuti oleh pihak UNHCR. Sebagai salah satu negara yang menampung pengungsi Rohingya, Indonesia memiliki serangkaian aturan hukum yang mengatur tentang pengungsi. Namun, aturan hukum yang ada di Indonesia belum sepenuhnya dapat digunakan untuk menangani permasalahan-permasalahan pengungsi yang masuk. Sebagai negara yang memiliki dasar negara 'Kemanusiaan yang adil dan beradab', Indonesia hanya membantu para korban atas dasar kemanusiaan dengan cara menampung mereka sampai beban pengungsi menjadi lebih ringan. Indonesia memberikan batasan waktu tinggal kepada pengungsi asal Rohingya yang ada di Rudenim seluruh Indonesia selama 10 tahun. Setelah masa penampungan yang ditetapkan berakhir, Indonesia sudah tidak bertanggung jawab dan tidak akan memberikan perlindungan lagi terhadap para pengungsi lintas batas negara tersebut. Penyelesaian kasus ini tidak hanya melibatkan negara-negara ASEAN, namun Indonesia juga harus bekerja sama dengan komunitas- komunitas internasional lain yang secara fokus juga membahas mengenai permasalahan yang sama. Indonesia yang merupakan salah satu negara penampung pengungsi asal Rohingya bekerja sama dengan ASEAN, PBB, dan IOM untuk bekerja bersama 
dalam penanganan permasalahan tersebut. Posisi Indonesia dan Myanmar sebagai anggota ASEAN telah mendorong Indonesia dan aktor-aktor lain yang terlibat untuk segera membahas masalah ini secara bersama-sama dalam forum-forum internasional (ASEAN).

\section{DAFTAR PUSTAKA}

Aryanto, Heri. "Kondisi Faktual Rohingya di Indonesia(Laporan Hasil Pencarian Fakta di Aceh, Medan, dan Tanjung Pinang)," 2013. https://indonesia4rohingyadotorg.files.wordpress.com/2013/03/kondisifaktu al-muslim-rohingya-di-indonesia.pdf.

Baehr, Peter et al, (2001) Instrumen Nasional Pokok Hak-Hak Asasi Manusia, jakrta: Yayasan Oobor Indonesia

Bowler Jr, Gary M. (2010). Netnography: A Method Specically Designed to Study Culturesand Communities Online.

Chyntia P. Scheneider, "Cultural Diplomacy : Hard to Define, But You"d Know it if YouSaw it", The Brown Journal of World Affairs, Fall/Winter, Vol. XIII, Issues I, pp. 191, 2006.

Creswell, J. W. (2007). Qualitative inquiry and Research Design: Choosing Among Five Approaches. United States of America : Sage Publication, Inc.

Friedmen, J. 1991. Cultural Identity andGlobal Process. London: sagepublication.

Geertz, C. 1983. Local Knowledge: FurtherEssays in InterpretativeAnthropology. New York: Basic book.

James Anderson (2002), TransnationalDemocracy, Political Spaces and Border Crossings,New York: Routledge, 1.

Kozinets, Robert V. (2002). The Field Behind the Screen: Using Netnography for Marketing Research in Online Communities. (February 2002). Journal of Marketing Research volume 39, No. 1. pp. 61-72.

Saville-Troike, Muriel. 2003. The Ethnography of Communication: An Introduction. UK: Blackwell Publishing

Susanti, Aviantina dkk 2014, penyelesaian kasus pelanggaran ham berat terhadap etnis rohingya di Myanmar berdasarkan hukum internasional.

Pauline Keer and Geoffrey Wiseman, Diplomacy in A Globalizing World. New York :Oxford University Press, 2013

James N.Rosenau, Gavin Boyd, Kenneth W. Thompson. 1976. World Politics: An Introduction. New York: The Free Press, hal. 15

Woodward, K. 1997. Identity andDifference. London: Thousand Oaks.New Delhi: Sage Publication.

Triono, 2014. Peran ASEAN Dalam Penyelesaian Konflik Etnis Rohingya. Jurnal TAPIs Vol.10 No.2 Juli-Desember

Nur, Sandy Ikfal Raharjo, 2015. Peran Identitas Agama dalam Konflik di Rakhine Myanmar Tahun 2012-2013. Jurnal Kajian Wilayah, Vol.6 No. 1. 